Available online on 15.03.2019 at http://ujpr.org
Universal Journal of Pharmaceutical Research
An International Peer Reviewed Journal
Open access to Pharmaceutical research

\title{
PLASMA FERRITIN AND HEPCIDIN LEVELS IN PATIENTS WITH TYPE 2 DIABETES MELLITUS
}

Ikram Ayad Anwar AL-Adhami ${ }^{1}$, Hassan A. Al-Shamahy ${ }^{2}$, Ali M. Al-Meeril ${ }^{1}$ (D)

${ }^{\prime}$ Departement of Biochemistry Faculty of Medicine and Health Sciences, Sana'a University, Republic of Yemen.

${ }^{2}$ Medical Microbiology and Clinical Immunology, Faculty of Medicine and Health Sciences, Sana'a University, Republic of Yemen.

\section{ABSTRACT}

Objective: Iron disorder and abnormal expression of hepcidin play important roles in many diseases, but it is still unclear in type 2 diabetes mellitus (T2DM). Current study aimed to assess iron, ferritin and hepcidin levels in plasma of with or without T2DM and evaluated increased body iron stores as risk factor for developing T2DM.

Methods: Plasma samples were collected from 88 participants, who were categorized into 2 groups based on the presence or absence of T2DM. Demographics and general health parameters were recorded. Chemiluminescence microparticle immunoassay and enzyme-linked immunosorbent assay were used to detect iron, ferritin and hepcidin concentrations. The geometric mean \pm SD of the plasma level of hepcidin, ferritin, iron and insulin among T2DM comparing with that of healthy controls were evaluated. Results: Plasma ferritin and hepcidin levels in T2DM group were higher than in the control group $(P<0.05)$. The geometric mean \pm SD of hepcidin and ferritin for T2DM were $41.1 \pm 23.3 \mu \mathrm{g} / \mathrm{l}$ and $227.2 \pm 156.1 \mathrm{gg} / \mathrm{l}$ respectively; higher than the $15.2 \pm 2.3 \mu \mathrm{g} / 1 \mathrm{and}$ $114.4 \pm 60.4 \mathrm{gg} / \mathrm{l}$ of controls respectively. There was a significant associated between high level of plasma hepcidin $(\mathrm{OR}=2.75)$ and ferritin $(\mathrm{OR}=2.24)$; with T2 DM.

Conclusion: In conclusion: the regulation of body iron, an essential but also toxic element is strictly controlled by a small peptide hormone hepcidin. The present data demonstrated that the higher hepcidin level in diabetic patients may be due to that higher ferritin, the elevated hepcidin might have adaptive value through down-regulated iron absorb and play an important role in pathogenesis of T2 DM.

Keywords: Association, Ferritin, Hepcidin, Type 2 diabetes mellitus, Yemen.

Article Info: Received 1 January 2019; Revised 15 February; Accepted 3 March, Available online 15 March 2019

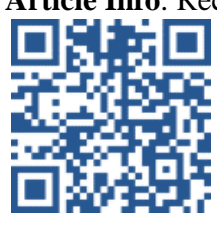

\section{Cite this article-}

AL-Adhami IAA, Al-Shamahy HA, Al-Meeril AM. Plasma ferritin and hepcidin levels in patients with type 2 diabetes mellitus. Universal Journal of Pharmaceutical Research. 2019; 4(1): 1-6.

DOI: https://doi.org/10.22270/ujpr.v4i1.231

Address for Correspondence

Prof. Hassan A. Al-Shamahy, Faculty of Medicine and Heath Sciences, Sana'a University, P.O. Box 775 Sana'a, Yemen. Phone: +967-770299847, E-mail: shmahe@yemen.net.ye

\section{INTRODUCTION}

Type 2 diabetes mellitus (T2DM) is characterized by chronic hyperglycemia caused by impaired insulin secretion and/or insulin resistance ${ }^{1}$. The role of micronutrients in the etiology of T2DM is not well established. Several lines of evidence suggest that iron play may a role in the pathogenesis of T2DM1. Iron is an indispensable nutrient for the human body; it is essential to maintain systemic iron homeostasis because iron disorder in the body can lead to various clinical diseases ${ }^{2}$. Recent facts suggest that increased body iron stores play a role in the pathogenesis of T2DM. Yeap et al., ${ }^{3}$ detected serum ferritin, iron, and transferrin saturation among 1834 men and 2351 women and reported that higher serum ferritin levels were independently associated with T2DM. In view of the fact that ferritin is generally used as a marker of body iron stores, this study suggested that increased body iron stores is a risk factor for T2DM ${ }^{3}$. Excessive systemic iron can trigger oxidative stress injury in hepatocytes and pancreatic $\beta$ cells, forming the basis of diabetes, which may cause insulin resistance, reduction in insulin secretion, and eventually, development of T2DM ${ }^{4,5}$. In addition, it has been reported that insulin can directly up-regulate hepcidin expression in hepatocellular carcinoma (HepG2) cells by enhancing signal transducers and activators of transcription 3 (STAT3) protein synthesis and DNA binding activity ${ }^{6}$, indicating that insulin disorder in T2DM can lead to inadequate hepcidin concentrations. Evidence suggests to us that insulin resistance accompanied by insufficient hepcidin levels can progress to overt diabetes through more dysfunction of cells via iron overload $^{7}$. Hepcidin, a key hormone synthesized in the 
liver, can regulate iron homeostasis ${ }^{8}$; it can prevent iron efflux from macrophages, enterocytes and hepatocytes into the plasma by inducing internalization and degradation of the iron exporter ferroportin in these cells ${ }^{9}$, which indicates that the iron overload is further aggravated by inadequate hepcidin in T2DM. Hepcidin expression can be regulated by iron-mediated pathways through signaling of JAK/STAT and $\mathrm{BMP} / \mathrm{SMAD}^{10}$. Iron stores can be detected using several techniques including liver biopsy ${ }^{11}$, iron stains on bone marrow trephine biopsy ${ }^{\mathbf{1 2}}$, and serological detection. Serum ferritin level is now widely used in clinical practice and is considered the most convenient and cost-effective method to detect iron load ${ }^{3}$. Also serum hepcidin has been proved to be an indicator of iron load ${ }^{13}$. Moreover, the serum hepcidin/ferritin ratio has been used to evaluate iron metabolism of the body as it represents both body iron load and adequacy of hepcidin production for a given iron load ${ }^{14}$. We aimed to assess iron, ferritin and hepcidin levels in serum of with or without T2DM and evaluated increased body iron stores as risk factor for developing T2DM Since ferritin is commonly used as a marker of body iron stores.

\section{SUBJECTS AND LABORATORY METHODS Subject selection}

After receiving approval from the Ethical Committee, we recruited $46 \mathrm{~T} 2 \mathrm{DM}$ patients, and 42 healthy individuals; the age of the participants ranged 2565 years. All participants provided a written informed consent, and all steps of the clinical examination and sampling procedures were explained to each participant. Participants were diagnosed with T2DM by specialist physicians at the hospital according to the American Diabetes Association criteria ${ }^{15}$. Data regarding demographic and clinical characteristics, including age, body mass index (BMI), fasting blood glucose (FBG), triglyceride (TG), cholesterol (CHOL), high-density lipoprotein (HDL), low-density lipoprotein (LDL), alanine transaminase (ALT), and aspartate transaminase (AST), were recorded in physical examination reports of all participants.

\section{Collection and storage of blood samples}

Blood samples were collected from the antecubital fossa by venipuncture using a 20 -gauge needle with a 5 -mL syringe. All collections were performed by welltrained nurses at the nursing station. Plasma was separated from blood by centrifuging at $3000 \mathrm{rpm}$ for 5 min. Blood samples which occurred hemolysis would be discarded. Each plasma sample was given a tracking number and stored at $-20^{\circ} \mathrm{C}$ until further analysis.

\section{Laboratory Tests}

Ferritin and hepcidin were tested in serum samples using chemiluminescence microparticle immunoassay (CMIA) and enzyme-linked immunosorbent assay (ELISA) (Roche, Germany), respectively. The tests were performed according to the manufacturer's instructions described in the assay procedure. A twostep immunoassay was required. Ferritin present in the sample binds to antiferritin-coated microparticles. After washing, antiferritin acridinium conjungate was added. Subsequently, pre-trigger and trigger solutions were added to the reaction mixture; the resulting chemiluminescent reaction was measured as relative light units (RLUs).

\section{Data analysis}

The analysis of data was done by Epi Info version 6 statistical program (CDC, Atlanta, USA), where the chi-square $(\chi 2)$ and probability value $(p)$ was calculated for the test of significance by comparing the geometric mean \pm SD of the plasma level of hepcidin, ferritin, iron and insulin among cases (type $2 \mathrm{DM}$ ) comparing with that of healthy controls. In addition, Odd's ratio (OR), $95 \%$ confidence interval $(95 \% \mathrm{CI})$ were added to estimate the associated OR for high level of hepcidin, ferritin and iron with T2DM comparing with that of healthy controls. A $p$ value $<0.05$ was considered significant.

\section{Ethical approval}

We obtained written consent from all cases. Assent was taken from participants before collecting the specimens. The study proposal was evaluated and approved by the Ethics Committee of Faculty of Medicine and Health Sciences, Sana'a University.

\section{RESULTS}

Table 1 summarizes the demographic characteristics of study participants: the mean participant age in the T2DM and control groups was 25.5 \pm 2.8 , $24.09 \pm 2.82$ years, respectively. The age of T2DM patients ranged from 30 to 65 years, while for healthy control ranged from 25 to 56 years. The mean participant BMI $\left(\mathrm{kg} / \mathrm{m}^{2}\right)$ in the T2DM and control groups was $50.05 \pm 9.54$ and $33.63 \pm 9.75 \mathrm{~kg} / \mathrm{m}^{2}$ respectively. Fasting blood glucose levels were significantly higher in patients with T2DM than in those without T2DM $(P<0.05)$. However, no significant intergroup differences were noted in terms of sex, CHOL, HDL and LDL $(P>0.05)$ (Table 1).

Table 1: The comparison of parameters between type $2 \mathrm{DM}$ and control groups.

\begin{tabular}{|c|c|c|c|c|c|}
\hline \multirow{2}{*}{$\begin{array}{l}\text { Biochemical } \\
\text { parameters }\end{array}$} & \multicolumn{2}{|c|}{ Type 2 DM, n= 46} & \multicolumn{2}{|c|}{ Healthy control, $n=42$} & \multirow[t]{2}{*}{$P$ value } \\
\hline & $\begin{array}{r}\begin{array}{c}\text { Geometric } \\
\text { mean }\end{array} \\
\end{array}$ & $\begin{array}{l}\text { Min-Max } \\
\text { SDD }\end{array}$ & $\begin{array}{r}\text { Geometric } \\
\text { mean }\end{array}$ & $\begin{array}{l}\text { Min-Max } \\
\pm \text { SD }\end{array}$ & \\
\hline $\mathrm{BMI} \mathrm{kg} / \mathrm{m}^{2}$ & $50.05 \pm 9.54$ & - & $33.63 \pm 9.75$ & - & 0.001 \\
\hline Age & $25.45 \pm 2.8$ & $\begin{array}{c}30-65 \\
\text { years }\end{array}$ & $24.91 \pm 2.82$ & $30-56$ & 0.908 \\
\hline FBS mg/dl & $219.8 \pm 73.8$ & $128-400$ & $95.2 \pm 7$ & $82-108$ & 0.001 \\
\hline HDL mmol/l & $1.06 \pm 0.32$ & $0.5-2.5$ & $1.06 \pm 0.2$ & $0.7-1.7$ & 0.908 \\
\hline LDL mmol/l & $3.1 \pm 0.81$ & $1.7-5.2$ & $2.91 \pm 0.8$ & $1.3-4.6$ & 0.394 \\
\hline Triglycerides mmol/l & $2.3 \pm 1.7$ & $0.7-11.9$ & $1.5 \pm 0.5$ & $0.6-2.6$ & 0.002 \\
\hline T. cholesterol mmol/l & $5.4 \pm 1.1$ & $3.8-8.4$ & $4.97 \pm 0.99$ & $2.6-6.9$ & 0.054 \\
\hline
\end{tabular}


Table 2: The plasma level of hepcidin, ferritin, iron and insulin among cases (type 2 DM) and healthy controls.

\begin{tabular}{|c|c|c|c|c|c|}
\hline \multirow{2}{*}{$\begin{array}{l}\text { Biochemical } \\
\text { parameters }\end{array}$} & \multicolumn{2}{|c|}{ Type 2 DM, n=46 } & \multicolumn{2}{|c|}{ Healthy control, $n=42$} & \multirow[t]{2}{*}{$P$ value } \\
\hline & $\begin{array}{l}\text { Geometric } \\
\text { mean } \pm \text { SD }\end{array}$ & Min-Max & $\begin{array}{l}\text { Geometric } \\
\text { mean } \pm \text { SD }\end{array}$ & Min-Max & \\
\hline Hepcidin $\mu \mathrm{g} / \mathrm{l}$ & $41.1 \pm 23.3$ & $17.2-76.9$ & $15.2 \pm 2.3$ & $10.2-19$ & $<0.001$ \\
\hline Ferritin $0 \mathrm{~g} / \mathrm{l}$ & $227.2 \pm 156.1$ & $30.3-638.3$ & $114.4 \pm 60.4$ & $20.2-258$ & $<0.001$ \\
\hline Iron $\mu \mathrm{g} / \mathrm{dl}$ & $89.2 \pm 34.4$ & $17.3-158$ & $82.1 \pm 23.8$ & $24.3-132$ & 0.15 \\
\hline Insulin $\mu \mathrm{U} / \mathrm{ml}$ & $8.5 \pm 6$ & $2-32.1$ & $8.6 \pm 3.1$ & $3.4-17.1$ & 0.80 \\
\hline
\end{tabular}

Table 2 shows the geometric mean \pm SD of the plasma level of hepcidin, ferritin, iron and insulin among T2DM comparing with that of healthy controls. The geometric mean $\pm \mathrm{SD}$ of hepcidin $\mu \mathrm{g} / \mathrm{l}$ for $\mathrm{DM}$ patients were $41.1 \pm 23.3 \mu \mathrm{g} / \mathrm{l}$ higher than the $15.2 \pm 2.3 \mu \mathrm{g} / \mathrm{l}$ of healthy controls. In addition the hepcidin level for T2DM patients was ranged from $17.2 \mu \mathrm{g} / 1$ to $76.6 \mu \mathrm{g} / 1$ while for healthy controls was ranged from $10.2 \mu \mathrm{g} / 1$ to $19 \mu \mathrm{g} / \mathrm{l}$ only much lower than that of the T2 DM patients. The geometric mean $\pm \mathrm{SD}$ of ferritin $\mathrm{ng} / \mathrm{l}$ for T2DM were $227.2 \pm 156.1 \mathrm{gg} / \mathrm{l}$ higher than the $114.4 \pm 60.4 \mathrm{gg} / \mathrm{l}$ of healthy controls. In addition the ferritin level for T2DM was ranged from $30.3 \mathrm{gg} / \mathrm{l}$ to $638.3 \mathrm{gg} / \mathrm{l}$ while for healthy controls was ranged from $20.2 \mathrm{gg} / 1$ to $258 \mathrm{gg} / 1$ lower than that of the T2DM. The geometric mean $\pm \mathrm{SD}$ of iron $\mu \mathrm{g} / \mathrm{dL}$ for T2DM patients were $89.2 \pm 34.4 \mu \mathrm{g} / \mathrm{l}$ slightly higher than the $82.1 \pm 23.8$ $\mu \mathrm{g} / \mathrm{dL}$ of healthy controls. In addition the iron level for T2DM was ranged from $17.3 \mu \mathrm{g} / \mathrm{dl}$ to $158 \mu \mathrm{g} / \mathrm{dl}$ and for healthy controls was ranged from $24.3 \mu \mathrm{g} / \mathrm{dL}$ to 132 $\mu \mathrm{g} / \mathrm{dL}$ slightly lower than that of the T2DM. The geometric mean $\pm \mathrm{SD}$ of insulin $\mu \mathrm{U} / \mathrm{ml}$ for T2DM were $8.5 \pm 6 \mu \mathrm{U} / \mathrm{ml}$ is roughly similar to the $8.6 \pm 3.1 \mu \mathrm{U} / \mathrm{ml}$ of healthy controls. In addition the insulin level for T2DM was ranged from $2 \mu \mathrm{U} / \mathrm{ml}$ to $32.1 \mu \mathrm{U} / \mathrm{ml}$ and for healthy controls was ranged from $3.4 \mu \mathrm{U} / \mathrm{ml}$ to $17.1 \mu \mathrm{U} / \mathrm{ml}$ slightly lower than that of the T2DM. Table 3 shows the associated odds ratio of high levels of iron, hepcidin, ferritin, and insulin in T2 DM comparing with healthy controls. There was a significant associated Odds ratio between high level of plasma iron and type $2 \mathrm{DM}$ in which the associated $\mathrm{OR}$ is equal to 1.98 times, with $95 \% \mathrm{CI}=1.6-24, \chi^{2}=3.9$ and $\mathrm{p}=0.05$. Also, there was a significant associated Odds ratio between high level of plasma hepcidin and type 2 $\mathrm{DM}$ in which the associated $\mathrm{OR}=2.75$ with $95 \% \mathrm{CI}=2$ $3.8, \chi^{2}=26.7$ and $p<0.001$. Additionally, there was a significant associated Odds ratio between high level of plasma ferritin and T2DM in which the associated $\mathrm{OR}=2.24,95 \% \mathrm{CI}=1.74-2.9, \chi^{2}=12.7$ and $p<0.001$. As well, there was a non-significant associated Odds ratio between high level of plasma insulin and type $2 \mathrm{DM}$ $(\mathrm{OR}=3.9, \mathrm{p}=0.2)$.

\section{DISCUSSION}

Diabetes Mellitus is a predominant public health concern, affecting millions of people worldwide. The disease causes substantial morbidity and mortality and long term complications. In the last 15 years, it is recognized that, increased body iron stores are associated with the development of Glucose intolerance, gestational diabetes and Type-2 diabetes ${ }^{\mathbf{1 6}}$. The aim of current study was to confirm the association of increased plasma iron, hepcidin, and ferritin level with the development of glucose intolerance and Type2 diabetes comparing with plasma iron, hepcidin, and ferritin level of healthy controls.

In current study there was a significant association between high level of serum iron concentration $(>150$ $\mu \mathrm{g} / \mathrm{dl})$ with DM by means of associated odds ratio equal to 1.98 , comparing with healthy controls $(p=0.05)$. This result is similar to that reported by Wrede et al., ${ }^{17}$ and Cavallo et al., ${ }^{18}$ in which increased serum iron negatively correlate with insulin sensitivity and the presence of insulin resistance syndrome. This negative correlation can be explained by the significant tissue accumulations of iron can lead to pathology in the liver, heart, endocrine organs, and musculoskeletal system $^{14}$. Excess iron deposition in the pancreas is known to cause a secondary form of diabetes, which has lead to speculation that higher concentrations of iron may increase the risk of developing diabetes. Earlier studies provided mixed evidence in support of the iron-diabetes hypothesis, and consequently the hypothesis was largely dismissed ${ }^{19}$. The existence of an iron regulatory hormone was postulated primarily to account for the observed interactions between the anatomically distinct sites of iron absorption, recycling and utilization.

Hepcidin is now acknowledged to be the main iron regulatory hormone. It is a 25 -amino acid peptide exclusively synthesized by the liver, initially identified as part of a search for novel antimicrobial peptides ${ }^{20,21}$. There was no indication that it had an additional role in iron metabolism until 2001, when mouse studies were published showing that hepatic hepcidin mRNA synthesis was induced by iron loading ${ }^{22,23}$. In current study there was a highly significant association between high level of serum hepcidin concentration (>75 $\mu \mathrm{g} / \mathrm{dl}$ ) with T2DM by means of associated odds ratio equal to $2.75(95 \% \mathrm{CI}=2-3.78)$ times comparing with healthy controls, with $\chi^{2}$ equal to 26.7 , and $\mathrm{p}$ value less than 0.001 (Table 3 ). This result is similar to that reported by Darshan and Anderson ${ }^{2}$ in which increased serum hepcidin is correlated with DM type 2 and insulin resistance DM cases.

The association Hepcidin with DM and iron concentration can be explained by that the rate of iron efflux into the plasma depends primarily on the plasma level of hepcidin; when iron levels are high the synthesis of hepcidin increases and the release of iron from enterocytes and macrophages are diminished. Conversely when iron stores drop, the synthesis of hepcidin is down-regulated and these cells release more iron $^{24,25}$.

What's more, in current study there was a significant association between high level of serum ferritin concentration $(>600 \mathrm{ng} / \mathrm{dl})$ with T2DM by means of 
associated odd's ratio equal to $2.24(p<0.001)$ comparing with healthy controls. This result is similar to that reported by Redmon et al., ${ }^{26}$, and Fleming ${ }^{27}$ in which increased serum ferritin is correlated with DM type 2 and insulin resistance DM cases.

Serum ferritin (SF) has been reported to negatively correlate with insulin sensitivity ${ }^{18}$ and the presence of insulin resistance syndrome ${ }^{28,29}$. Furthermore insulin resistance, compensated by Hyperinsulinaemia, sets in early even before the onset of frank diabetes mellitus and correlate well with indicators of iron overload and $\mathrm{SF}^{28}$. Additionally other evidence clear the effect of ferritin on iron overload and the encouraging the development of DM type 2 is that frequent blood donation lead to decrease iron stores, which in turn reduces post-prandal Hyperinsulinaemia in healthy volunteers and improves insulin sensitivity ${ }^{23}$.

Table 3: The associated odds ratio of high iron, hepcidin, ferritin, insulin, in type 2 DM comparing with healthy controls.

\begin{tabular}{|c|c|c|c|c|c|c|c|c|}
\hline \multirow[t]{2}{*}{$\begin{array}{l}\text { Biochemical } \\
\text { parameters }\end{array}$} & \multicolumn{2}{|c|}{$\begin{array}{c}\text { High level } \\
\text { DM }\end{array}$} & \multicolumn{2}{|c|}{$\begin{array}{l}\text { High level } \\
\text { control }\end{array}$} & \multirow[t]{2}{*}{ OR } & \multirow[t]{2}{*}{ CI } & \multirow[t]{2}{*}{$\chi^{2}$} & \multirow[t]{2}{*}{$\mathbf{P}$} \\
\hline & No & $\%$ & No & $\%$ & & & & \\
\hline Iron $\mu \mathrm{g} / \mathrm{dl}$ & 3 & 6.5 & 0 & 0 & 1.98 & $1.6-24$ & 3.9 & 0.05 \\
\hline Hepcidin $\mu \mathrm{g} / \mathrm{l}$ & 22 & 48 & 0 & 0 & 2.75 & $2-3.8$ & 26.7 & $<0.001$ \\
\hline Ferritin $0 \mathrm{~g} / \mathrm{l}$ & 12 & 26.1 & 0 & 0 & 2.24 & $1.74-2.9$ & 12.7 & $<0.001$ \\
\hline Insulin $\mu \mathrm{U} / \mathrm{ml}$ & 4 & 8.7 & 1 & 2.4 & 3.9 & $0.4-95.8$ & 1.63 & 0.2 \\
\hline
\end{tabular}

OR-Odds ratio $=$ Relative risk, CI- Confidence intervals, $\chi^{2}$ - Chi-square $=3.9$ or more significant, $p v$ - Probability value $=0.05$ or less significant

Insulin resistance, correlate well with total units of blood transfused, splenomegaly and SF in chronically transfused patients of thalassemia major ${ }^{28}$. Also, phlebotomy is followed by drop in serum glucose, serum Cholesterol, serum triglycerides and improvement in both beta cell secretion and peripheral insulin action in type-2 diabetes mellitus ${ }^{30}$. As well epidemiological studies suggest that high body iron stores are associated with insulin resistance and type 2 diabetes with high level of serum ferritin ${ }^{31,32}$. Also current study's result is suggested that $26.1 \%$ (Table 3) of T2DM patients (might developed IRS (Insulin Resistance Syndrome) this suggestion supported by Wrede et al., ${ }^{17}$ which reported a significant correlation between SF and the presence of IRS criteria in a large representative population.

Fernandez-Real et al., ${ }^{33}$ found that in general population increased body iron stores are possibly associated with occurrence of glucose intolerance, type-2 diabetes and gestational diabetes. Facchini, ${ }^{29}$ found significant reduction in serum insulin concentration after performing a $550 \mathrm{ml}$ phlebotomy in healthy volunteers. Bloodletting of $1500 \mathrm{ml}$ has been demonstrated to improve insulin sensitivity and to decrease C-peptide secretion in type-2 diabetes subjects who had decreased SF concentration. Similarly Dmochowski et al., ${ }^{34}$ and Jehn et al., ${ }^{35}$ reported in a study on thalassemic patients that SF concentration correlated negatively with insulin sensitivity and the conclusion of the study showed a major and significant insulin resistance which may be compensated for by an elevated circulating insulin level. Dymock et al., ${ }^{36}$ and Swaminathan et al., ${ }^{37}$ reported significant reduction in total daily insulin dosage following phlebotomy and improvement in diabetic status of patients following venesection. Further epidemiological studies also support these findings which suggest that high body iron stores are associated with insulin resistance and type 2 diabetes ${ }^{38,39}$

In conclusion of current study examined the association between ferritin concentration and diabetes, and we found that serum ferritin concentration was strongly associated with newly diagnosed diabetes. Because these results are based on cases control data, any causal inference is speculative. These results support similar findings from other studies ${ }^{31,40}$. In current study high level ferritin found in $26.1 \%$ of DM similar to some studies, high ferritin concentrations were found in 6$33 \%$ of patients with type 2 diabetes, which suggests that ferritin concentration may be abnormally high among individuals with diabetes ${ }^{31,40}$. Several studies have produced mixed findings about differences in ferritin concentration between diabetic patients and control subjects ${ }^{41,42,43}$. One study suggested that treating diabetic patients with desferoxamine lowered ferritin concentrations and improved the management of diabetes ${ }^{44}$, but these findings were not confirmed in others studies ${ }^{19,45}$. At least three possible explanations may account for the elevated ferritin concentrations in participants with diabetes: First, elevated ferritin concentrations may represent elevated iron body stores. Second, ferritin is also an acute-phase reactant, and elevated ferritin concentrations may reflect inflammation. Third, delayed clearance of glycosylated ferritin in participants with diabetes may have led to elevated ferritin concentrations ${ }^{40,43,46}$.

The synthesis of hepcidin is also enhanced by an increased body iron stores ${ }^{47}$. Hepcidin levels were increased significantly in all diabetic patients compared with normal control in current research, and a significant positive correlation between hepcidin and ferritin which was marked in diabetic group (Table 2 and Table 3 ). The regulation of hepcidin by body iron acts as a feedback mechanism to allow sufficient iron to enter the plasma when the demand for iron is high, but to limit iron release into the plasma in times of iron sufficiency. Then, hepcidin acts as a negative regulator of intestinal iron absorption and macrophage iron release. Data of current study demonstrated that the elevated hepcidin in Type 2 DM patients may be due to those elevated ferritin levels, and this confirmed with study of Fang Jiang, et al. ${ }^{48}$. The confirmation of an increased risk of diabetes with moderately elevated 
ferritin levels could have clinical and public health consequences, since persons at high risk could be targeted for more intensive screening and preventive interventions ${ }^{39}$. From these points, the elevated hepcidin concentrations may have adaptive value through down-regulated iron absorb in patients with Type 2 DM. Hepcidin concentration may be useful to predict which patients could benefit from it although the potential use of hepcidin targeted therapeutics are yet available ${ }^{48}$.

\section{CONCLUSION}

The geometric mean \pm SD of the plasma level of hepcidin, ferritin, iron and insulin among cases (type 2 DM) were higher than that of healthy controls. The regulation of body iron, an essential but also toxic element is strictly controlled by a small peptide hormone hepcidin. The present data demonstrated that the higher hepcidin level in diabetic patients may be due to that higher ferritin, the elevated hepcidin might have adaptive value through down-regulated iron absorb and play an important role in pathogenesis of type 2 DM.

\section{RECOMMENDATION}

A wider knowledge of hepcidin regulation will provide us with novel tools for differential diagnosis, therapeutic regimes and monitoring of disorders of iron metabolism. However, a lot remains to be uncovered on the biology and function of hepcidin. Its signaling pathways are as yet to be delineated. Further studies are needed to define precisely the hepcidin role in iron metabolism homeostasis and its utility in the diagnosis and treatment of iron disorders. Also that more studies need to be performed regarding the role of ferritin in pre-diabetic stage as well as in type 2 diabetics. Finally prospective studies are needed to confirm whether elevated serum ferritin predicts insulin resistance and its associated conditions, or is merely a secondary marker of metabolic abnormalities.

\section{ACKNOWLEDGEMENTS}

Authors acknowledge the financial support of Sana'a University, Yemen.

\section{AUTHOR'S CONTRIBUTION}

All authors have worked equally for this work.

\section{CONFLICT OF INTEREST}

No conflict of interest associated with this work.

\section{REFERENCES}

1.Expert Committee on the $\mathrm{D}$, Classification of Diabetes $\mathrm{M}$ Report of the expert committee on the diagnosis and classification of diabetes mellitus. Diabetes Care 2003; 26(Suppl 1):S5-20. https://doi.org/10.2337/diacare.26.2007.S5

2.Wang L, Duan XL, Wang YZ, Chang YZ, Qian ZM. Progress of the study on iron disorder diseases. Sheng Li Ke Xue Jin Zhan 2007; 38(4):307-312.PMID: 18232299

3. Yeap BB, Divitini ML, Gunton JE, Olynyk JK, Beilby JP, McQuillan B, Hung J, Knuiman MW. Higher ferritin levels, but not serum iron or transferrin saturation, are associated with type 2 diabetes mellitus in adult men and women free of genetic haemochromatosis. Clin Endocrinol 2015; 82(4):525-532. https://doi.org/10.1111/cen.12529

4. Silva M, Bonomo Lde F, Oliveira Rde P, Geraldo de Lima W, Silva ME, Pedrosa ML. Effects of the interaction of diabetes and iron supplementation on hepatic and pancreatic tissues, oxidative stress markers, and liver peroxisome proliferator-activated receptor-alpha expression. J Clin Biochem Nutr 2011; 49(2):102-108. https://doi.org/10.3164/jcbn.10-135

5.Kumar J, Teoh SL, Das S, Mahakknaukrauh P. Oxidative stress in oral diseases: understanding its relation with other systemic diseases. Front Physiol 2017; 8:693. https://doi.org/10.3389/fphys.2017.00693

6. Wang H, Li H, Jiang X, Shi W, Shen Z, Li M. Hepcidin is directly regulated by insulin and plays an important role in iron overload in streptozotocin-induced diabetic rats. Diabetes 2014; 63(5):1506-1518.

https://doi.org/10.2337/db13-1195

7. Vela D, Sopi RB, Mladenov M. Low Hepcidin in diabetes mellitus: examining the molecular links and their clinical implications. Can J Diabetes 2018; 42(2):179-187.

https://doi.org/10.1016/j.jcjd.2017.04.007

8.Zhao N, Zhang AS, Enns CA. Iron regulation by hepcidin. J Clin Invest 2013; 123(6):2337-2343. https://doi.org/10.1172/JCI67225

9. Nemeth E, Tuttle MS, Powelson J, Vaughn MB, Donovan A, Ward DM, Ganz T, Kaplan J. Hepcidin regulates cellular iron efflux by binding to ferroportin and inducing its internalization. Science 2004; 306(5704):2090-2093. https://doi.org/10.1126/science.1104742

10. Poli M, Asperti M, Ruzzenenti P, Regoni M, Arosio P. Hepcidin antagonists for potential treatments of disorders with hepcidin excess. Front Pharmacol 2014; 5:86. https://doi.org/10.3389/fphar.2014.00086

11. Fischer R, Piga A, Harmatz P, Nielsen P. Monitoring longterm efficacy of iron chelation treatment with biomagnetic liver susceptometry. Ann N Y Acad Sci 2005; 1054:350 357. https://doi.org/10.1196/annals. 1345.043

12. Stuart-Smith SE, Hughes DA, Bain BJ. Are routine iron stains on bone marrow trephine biopsy specimens necessary? J Clin Pathol 2005; 58(3):269-272. https://doi.org/10.1136/jcp.2004.017038

13. Bah A, Pasricha S-R, Jallow MW, Sise EA, Wegmuller R, Armitage AE, Drakesmith H, Moore SE, Prentice AM. Serum Hepcidin concentrations decline during pregnancy and may identify Iron deficiency: analysis of a longitudinal pregnancy cohort in the Gambia. J Nutr 2017; 147(6):11311137. https://doi.org/10.3945/jn.116.245373

14. Sam AH, Busbridge M, Amin A, et al. Hepcidin levels in diabetes mellitus and polycystic ovary syndrome. Diabet Med 2013; 30(12):1495-1499. https://doi.org/10.1111/dme.12262

15. American Diabetes A. Diagnosis and classification of diabetes mellitus. Diabetes Care 2008; 31(Suppl 1):S55-S60. https://doi.org/10.2337/dc14-S081

16. Fernandez-Real JM, Vayreda M, Richart C, Gutierrez C, Broch M, Vendrell J, Ricart W: Circulating interleukin 6 levels, blood pressure, and insulin sensitivity in apparently healthy men and women. J Clin Endocrinol Metab 2001; 86:1154-1159. https://doi.org/10.1210/jcem.86.3.7305

17. Wrede CE, Buettner R, Bollheimer LC,Scholmerich J, Palitzsch KD, Hellerbrand C. Association between SF and the insulin resistance syndrome in a representative population. Eur J Endocrinol 2006; 154:333-40. https://doi.org/10.1530/eje.1.02083

18. Cavallo-P, Giovanni P, Franco C, et al. Insulin resistance and hyperinsulinemia in homozygous B-Thalassemia. Metabolism 1996; 44:281-86. https://doi.org/10.1016/0026-0495(95)90155-8

19. Redmon JB, Robertson RP: Iron and diabetes: an attractive hypothesis. Mayo Clin Proc 1994; 69:90-92. https://doi.org/10.1016/S0025-6196(12)61620-6 
20. Ganz T, Nemeth E. Iron imports. IV. Hepcidin and regulation of body iron metabolism. Am J Physiol Gastrointest Liver Physiol 2006; 290: G199-203. https://doi.org/10.1152/ajpgi.00412.2005

21. Darshan D, Anderson GJ. Interacting signals in the control of hepcidin expression. Biometals 2009; 22: 77-87. https://doi.org/10.1007/s10534-008-9187-y

22. Nicolas G, Viatte L, Lou DQ, Bennoun M, Beaumont C, Kahn A, Andrews NC, Vaulont S. Constitutive hepcidin expression prevents iron overload in a mouse model of hemochromatosis. Nat Genet 2003; 34:97-101. https://doi.org/10.1038/ng1150

23. Fleming MD. The regulation of hepcidin and its effects on systemic and cellular iron metabolism. Hematology Am Soc Hematol Educ Program 2008; (2008): 151-158.

https://doi.org/10.1182/asheducation-2008.1.151

24. Papanikolaou G, Tzilianos M, Christakis JI, Bogdanos D, Tsimirika K, MacFarlane J, Goldberg YP, Ganz T, and Nemeth E. Hepcidin in iron overload disorders. Blood 2005; 105: 4103-4105. https://doi.org/10.1182/blood-2004-12-4844

25. Park CH, Valore EV, Waring AJ, and Ganz T. Hepcidin, a urinary antimicrobial peptide synthesized in the liver. J Biol Chem 2001; 276: 7806-7810 https://doi.org/10.1074/jbc.M008922200

26. Redmon JB, Pyzdrowski KL, Robertson RP: No effect of deferoxamine therapy on glucose homeostasis and insulin secretion in individuals with NIDDM and elevated serum ferritin. Diabetes 1993; 42:544-549.

27. Fleming RE. Advances in understanding the molecular basis for the regulation of dietary iron absorption. Curr Opin Gastroenterol 2005; 21:201-6. https://doi.org/10.1016/j.jinsphys.2007.06.009

28. Suvarna J,Ingle H, Deshmukh CT. Insulin resistance and beta cell function in chronically transfused patients of thalassemia major. Indian Pediatr 2006; 43:393-400.

29. Facchini FS. Effect of phlebotomy on plasma glucose and insulin concentrations. Diabetes care 1988; 21:2190. https://doi.org/10.2337/diacare.21.12.2190a

30. Uzma Z, Qureshi HJ, Karim A. Insulin resistance and serum parameters of iron status in type 2 diabetics. Pak J Physiol 2011; 7(2):26-29.

31. Smotra S, Tandon VR, Sharma S, Kudyar RP. Serum ferritin and type 2 diabetes mellitus. JK Science 2007; 9:164-6. https://doi.org/10.1002/dmrr.2394

32. Bozzini C, Tenuti I, Givelli D, Lotto V, Olvivieri O, FrisoS et al. Prevalence of body iron excess in metabolic syndrome. Diabetes Care 2005; 28:2061-3. https://doi.org/10.2337/diacare.28.8.2061

33. Fernandez-Real JM, Lopez-Bermejo A, Ricart W. Cross-talk between iron metabolism and diabetes. Diabetes 2002; 51:2348-54. https://doi.org/10.2337/diabetes.51.8.2348

34. Dmochowski. K, Finegood DT, Fran Combe W, Tyler B Z B. Factors determining glucose tolerance in patients with thalassemia. Major J Clin Endocrinal Metab 1993; 77:47883. https://doi.org/10.1210/jcem.77.2.8345055

35. Jehn M, Clark JM, Guallar E. Serum ferritin and risk of metabolic syndrome in U.S. adults. Diabetes Care 2004; 27:2422-8. https://doi.org/10.2337/diacare.27.10.2422
36. Dymock IW, Cassar J, Pyke DA, Oakley WG, Williams R: Observations on the pathogenesis, complications and treatment of diabetes in 115 cases of haemochromatosis. Am J Med 1972; 52:203-210. https://doi.org/10.1016/0002-9343(72)90070-8

37. Swaminathan S, Alam MG, Fonseca VA, Shah SV. The role of iron in diabetes and its complications. Diabetes Care 2007; 30:1926-33.https://doi.org/10.2337/dc06-2625

38. Loebstein R, Lehotay DC, Luo X, et al. Diabetic enephropathy in hypertransfused patients with betathalassemia. The role of oxidative stress. Diabetes Care 1998; 21:1306-9.https://doi.org/10.2337/diacare.21.8.1306

39. Guo Lin-Na , Yan-Zong Yang, and Yun-Zhi Feng. Serum and salivary ferritin and hepcidin levels in patients with chronic periodontitis and type 2 diabetes mellitus. BMC Oral Health 2018; 18: 63. https://doi.org/10.1186/s12903-018-0524-4

40. Kim CH, Kim HK, Bae SL, Park JY, Lee KU. Association of elevated serum ferritin concentration with insulin resistance and impaired glucose metabolism in Korean men and women. Metabolism 2011; 60:214-20. https://doi.org/10.1016/j.metabol.2010.03.007

41. Eroglu D, Zeyneloglu HB. Metabolic disorders in patients with recent gestational diabetes mellitus. J Obstet Gynaecol Res 2006; 32:408-15. https://doi.org/10.1111/j.1447-0756.2006.00418.x

42. Green A., R. Basile, J.M. Rumberger. Transferrin and iron induce insulin resistance of glucose transport in adipocytes. Metabolism 2006; 55:1042-1045. https://doi.org/10.1016/j.metabol.2006.03.015

43. Hashimoto N, Suzuki Y, Haruki AT, Sakuma Y, Iwai R, Takahashi $H$. The association between the ferritin concentration and the serum insulin resistance markers, and follow up analysis for three years in non diabetic Japanese men. Diabetes Care 2008; 31:55-60. https://doi.org/10.7860/JCDR/2015/13480.6564

44. Marshall S M: Recent advances in diabetic nephropathy. Post graduate Medical J 2004; 80:620-33. http://dx.doi.org/10.1136/pgmj.2004.021287

45. O'Brien T, Basset B, Burray DM, Dinneen S, O'Sullivan DJ: Usefulness of biochemical screening of diabetic patients for hemochromatosis. Diabetes Care 1990; 13:532-534. https://doi.org/10.2337/diacare.13.5.532

46. Kaye TB, Guay AT, Simonson DC: Noninsulin- dependent diabetes mellitus and elevated serum ferritin level. J Diabetes Complications 1993; 7:246-249. https://doi.org/10.1016/0891-6632(93)90008-5

47. Piperno A, Mariani R, Trombini P, Girelli D. Hepcidin modulation in human diseases: from research to clinic. World J Gastroenterol 2009; 15: 538-551. https://doi.org/10.3748/wjg.15.538

48. Fang Jiang, Zhen-Zhen Sun, Yue-Ting Tang, Chuanqing Xu, Xiao-Yang Jiao, Hepcidin expression and iron parameters change in Type 2 diabetic patients; diabetes research and clinical practice 2011 ; 93:43-44 https://doi.org/10.1016/j.diabres.2011.03.028 